\title{
neofilolog
}

Czasopismo Polskiego Towarzystwa Neofilologicznego

ISSN 1429-2173, elSSN 2545-3971, 2021, NR 56/2, 337-356

http://dx.doi.org/10.14746/n.2021.56.2.11

http://poltowneo.org/

Tomasz Róg

Państwowa Uczelnia Stanisława Staszica w Pile https://orcid.org/0000-0002-9220-3870

tomaszrog@yahoo.co.uk

\section{Trudność zadania komunikacyjnego a bogactwo leksykalne wypowiedzi uczniów}

\section{Task difficulty influences learners' lexical complexity}

Task-based language teaching has recently become a mainstream research area in second language acquisition studies. One of the underexplored areas is task design and its influence on the measures of complexity, accuracy, and fluency. While most previous research into task design focused on manipulating planning time, note-taking, or task familiarity, one of the promising lines of investigation is how task difficulty may also be conducive to $L 2$ acquisition. Task difficulty is understood as the cognitive burden placed on a learner performing a task. In the current study learners of English as a foreign language $(n=28)$ performed three differently designed oral communicative tasks of increasing difficulty: (1) a brainstorming task, (2) a sorting and ordering task, and (3) a problemsolving argumentative task. Task difficulty, i.e. having to employ higherorder thinking skills improved learners' L2 lexical complexity as measured by lexical diversity, lexical density, and word-frequency counts.

Keywords: task-based language teaching, task difficulty, lexical diversity, lexical density, lexical complexity, creativity

Słowa kluczowe: podejście zadaniowe, trudność zadania, zróżnicowanie leksykalne, gęstość leksykalna, bogactwo leksykalne, kreatywność 


\section{Wstęp}

Podejście zadaniowe (ang. task-based approach) jest obecnie jednym z bardziej popularnych podejść do nauczania języków obcych. Rekomendują je ministerstwa edukacji m.in. w Austrii, Belgii, Chinach i Kanadzie oraz Europejski System Opisu Kształcenia Językowego (2003). Jest ono jednocześnie jednym z głównych nurtów badawczych w obrębie glottodydaktyki (Ellis i in., 2020). Zarówno badaczy, jak i nauczycieli interesuje w szczególności rola i konstrukcja zadań komunikacyjnych, które stają się podstawowym elementem wpływającym na organizację programu nauczania (Ellis, Shintani, 2014; Long, 2015; Bygate, 2018; Ellis i in., 2020). Zadania komunikacyjne pozwalają na w miarę autentyczne użycie języka z jednoczesnym zwróceniem uwagi na jego formę (Nunan, 2004; Ellis, Shintani, 2014), wpisują się w szerszy paradygmat podejścia działaniowego (Gębal, 2019) i nauczania skoncentrowanego na osobie ucznia (Janowska, 2019) oraz przygotowują uczniów do podejmowania działań językowych w ramach ich (przyszłych) potrzeb akademickich, zawodowych i osobistych (Révész, Gurzynski-Weiss, 2016).

W ramach podejścia zadaniowego skuteczna nauka języka w dużej mierze zależy od pomyślnie zaprojektowania zadania. Wcześniejsze badania wykazały, że jego konstrukcja może wpływać na interakcje między uczącymi się a ich nauczycielami, wspierać spostrzeganie form językowych i ułatwiać opanowywanie języka (Skehan, 1989; Robinson, 2001; Long, 2015; Kim, 2015). Podczas gdy większość wcześniejszych badań nad konstrukcją zadania koncentrowała się na wymaganiach językowych stawianych w nim uczniom (np. Préfontaine, Kormos, 2015), jednym z nowszych, obiecujących kierunków jest manipulowanie trudnością poznawczą zadania w celu zaobserwowania, w jaki sposób może ono sprzyjać nabywaniu języka obcego (Révész, Gurzynski-Weiss, 2016).

Pomimo rosnącego zainteresowania podejściem zadaniowym wiele kwestii wciąż pozostaje niewyjaśnionych. We wcześniejszych badaniach manipulowano takimi zmiennymi jak: czas na przygotowanie się do wypowiedzi ustnej (Ortega, 1999; Fu, Li, 2017), pozwalanie uczniom na przygotowanie notatek (Park, 2010), wykorzystanie znanej uczniom kategorii zadania (Skehan, 2009) czy zwiększanie liczby elementów do wykonania (Kim, 2018), niewiele z nich koncentrowało natomiast się na manipulowaniu trudnością zadania poprzez zwiększanie obciążenia poznawczego uczniów. W związku z powyższym mało wiadomo na temat związku między zwiększaniem trudności zadania a zmianami w bogactwie leksykalnym użytym w trakcie jego wykonywania.

W przedstawionym poniżej badaniu spróbowano częściowo wypełnić tę lukę poprzez analizę osiągnięć osób uczących się języka angielskiego jako obcego na poziomie średnio zaawansowanym $(n=28)$, którzy wykonali trzy różne 
zadania komunikacyjne o narastającym stopniu trudności: (1) zadanie polegające na wytw orzeniu konkretnej liczby pomystów, (2) zadanie wymagające porządkowania i sortowania tych pomystów oraz (3) zadanie wymagające rozwiązywania problemów i przedstawienia argumentów. Narastającą trudnością była zatem konieczność coraz bardziej kreatywnego myślenia. Wypowiedzi ustne uczniów zostały przeanalizowane pod kątem bogactwa leksykalnego (częstości występowania użytych słów, różnorodności i gęstości leksykalnej).

\section{Przegląd literatury}

\subsection{Trudność zadania - taksonomie}

Różne definicje zadania komunikacyjnego (Breen, 1989; Willis, 1996; Nunan, 2004, Ellis, Shintani, 2014) łącznie wskazują na jego następujące wymogi:

- powinno skupiać się przede wszystkim na znaczeniu, a nie na formach językowych;

- powinno zawierać lukę komunikacyjną, aby uczący się odczuli potrzebę przekazania wiadomości;

- powinno wymagać od uczących się polegania na dostępnych im zasobach językowych (przy czym zadania oparte na rozumieniu tekstów mogą zapewnić zasoby niezbędne do jego wykonania);

- powinno dać jasno określony i przewidywalny wynik (np. stworzenie harmonogramu czy zdobycie konkretnych informacji).

Zadanie różni się tym samym od ćwiczenia, gdyż o ile to drugie sprowadza się do realizacji przez uczniów pojedynczego celu (niekoniecznie komunikacyjnego, np. powtarzanie wymowy słowa), pierwsze - wymaga od nich wykonania serii czynności/działań służących osiąganiu celu komunikacyjnego i których efekty są także pozajęzykowe (Róg, 2020).

Określenie trudności zadania może być problematyczne na poziomie praktyki nauczycielskiej, ale ma dość konkretne umocowanie teoretyczne w trzech zbliżonych taksonomiach zaproponowanych przez Skehana (1998), Robinsona (2001) i Ellisa (2003).

W pierwszej z tych taksonomii, Skehan (1998) zaproponował trzy komponenty składające się na trudność zadania: (1) złożoność kodu (trudniejsze są zadania wymagające użycia bardziej złożonych struktur leksykalno-gramatycznych), (2) złożoność poznawczą (trudniejsze są zadania, które wymagają zaangażowania procesów myślenia wyższego rzędu) i (3) napięcie komunikacyjne (na trudność zadania wpływać mogą np. presja czasu, liczba uczestników, modalność i inne warunki wykonywania zadania).Trudność zadania w taksonomii 
Robinsona $(2001,2011)$ związana jest z tzw. złożonością zadania (ang. task complexity). Tą trudnością możemy manipulować na dwa sposoby, poprzez tzw. zmienne kierujące (ang. resource-directing variables) i rozpraszające (ang. resource- dispersing variables). Do tych pierwszych możemy zaliczyć np. wymaganie uzasadnienia wyników zadania, odnoszenia się do wydarzeń, które są odległe w czasie lub przestrzeni czy też zwiększanie ilości informacji, które uczniowie muszą przetworzyć. Do tych drugich możemy zaliczyć liczbę wykonywanych zadań, czas przeznaczony na przygotowanie do ich wykonania lub liczbę kroków, które uczniowie muszą wykonać w celu ich ukończenia. Tym samym złożoność zadania według Robinsona bardzo przypomina złożoność poznawczą ztaksonomii Skehana (1998). Co prawda Robinson wyróżnia w swoim modelu zmienną, której tłumaczenie na język polski oznacza właśnie trudność (ang. task difficulty), jednak ta trudność odnosi się do różnic indywidualnych pomiędzy uczącymi się (np. zdolność językowa, czy odczuwanie lęku językowego), jej sens jest więc bardziej ogólny, odnosi się do subiektywnych odczuć ucznia i jest poza kontrolą nauczyciela. W modelu Ellisa (2003) z kolei trudność zadania wyrażona jest, podobnie jak w modelu Skehana (1998) i Robinsona (2001), jako złożoność poznawcza. Jest ona więc wyraźnie związana z treściami pojawiającymi się w danym zadaniu. Zdaniem Ellisa, trudniejsze zadania to te, które są bardziej abstrakcyjne, zawierają większą liczbę elementów i związków między nimi, mają mniej jasną strukturę lub są zorientowane na inny czas i inne miejsce. Na trudność wpływ ma również kategoria zadania (np. tworzenie list, porządkowanie, rozwiązywanie problemów), przy czym im lepiej znane uczniom procedury danej kategorii, tym będzie ono dla nich łatwiejsze. Ostatnim elementem, na który zwraca uwagę Ellis (2003), są procesy poznawcze wymagane do wykonania zadania. Bardziej zaawansowane procesy (np. manipulowanie informacjami, ocenianie przydatności faktów, osądzanie, wyciąganie wniosków, wymyślanie rozwiązań) będą trudniejsze od procesów niższego rzędu (np. klasyfikowania czy opisywania zdarzeń).

Uogólniając powyższe rozważania teoretyczne, możemy przyjąć, że na trudność zadania komunikacyjnego wpływ będą miały następujące czynniki:

- czas przeznaczony na przygotowanie się i wykonanie zadania,

- struktury leksykalno-gramatyczne konieczne do wykonania zadania,

- $\quad$ kanał przekazu (np. czy uczniowie będą zaangażowani w wypowiedź pisemną czy ustną),

- znajomość kategorii zadania/ zrozumienie wymaganych procedur,

- odnoszenie się do zdarzeń odległych w czasie i przestrzeni,

- liczba kroków/etapów wymaganych do wykonania zadania,

- procesy myślowe, które uczeń musi zaangażować do wykonania zadania. 


\subsection{Trudność zadania - badania empiryczne}

Obserwując wpływ powyższych czynników na wykonanie zadania, badacze skupiają się przede wszystkim na miarach płynności, poprawności i bogactwa leksykalno-gramatycznego (Ellis i in., 2020). Czas realizacji jest także jednym z najczęściej badanych czynników (Taguchi, 2007). Dysponując odpowiednio długim czasem na przygotowanie się np. do wypowiedzi ustnej, uczniowie mogą skorzystać z dodatkowych pomocy, takich jak słowniki, mogą przygotować notatki, zrobić plan swojej wypowiedzi lub po prostu przemyśleć, co chcą powiedzieć. Stan badań nad planowaniem pokazuje, że sprzyja ono większej płynności i bogactwu językowemu uczniów, ale jego wpływ na poprawność bywa zmienny. Przykładowo, w jednym z wcześniejszych badań (Wigglesworth, 1997) zwiększony czas przeznaczony na zaplanowanie wypowiedzi pomógł zaawansowanym uczniom zwiększyć bogactwo językowe i usprawnić płynność wypowiedzi, lecz nie wpłynął znacząco na ich poprawność. W większości badań uczniowie otrzymywali około 10 minut na przygotowanie (np. Ortega, 1999; Fu, Li, 2017) i, jak wykazano (M ehnert, 1998), dłuższy czas korelował pozytywnie z większą płynnością. Poprawność językowa zwiększała się natomiast u planujących krócej, tj. uczniowie przygotowujący się przez minutę byli bardziej poprawni niż ci, którzy planowali realizację od 5 do 10 minut. Dłuższy czas na przygotowanie pozwala więc uczącym się skupić na wymyślaniu treści, co odciąga ich uwagę od zastanawiania się nad formą języka. Część badaczy (Philip, Oliver, Mackey, 2006; Wigglesworth, Elder, 2010; Li, Chen, Sun, 2015; Li, Fu, 2016) wskazało, że czas optymalny na planowanie to 1 do 3 minut, co zdaje się dość praktyczne, biorąc pod uwagę ograniczony czas lekcji w klasie.

Badania dotyczące pozostałych czynników wpływających na trudność zadania są dość nieliczne. Adams i Nik (2014) na przykład, zbadali wpływ uprzedniej wiedzy uczniów dotyczącej tematyki zadania i wykazali, że wbrew intuicji, znajomość tematyki nie wpłynęła w żaden sposób na udział uczących się w interakcji. Badaniu poddano 42 studentów kierunków inżynierskich uczących się języka angielskiego, których zadaniem było prowadzenie rozmowy za pośrednictwem komunikatora internetowego i rozwiązanie problemu związanego z oprogramowaniem. Biorąc pod uwagę ilość „wyprodukowanego" przez każdego z uczestników języka oraz zabieranie przez nich głosu na czacie, Adams i Nik (2014) nie zauważyli żadnych istotnych różnic pomiędzy uczniami, którzy dobrze znali tematykę rozmowy a tymi, którzy nie wiedzieli na ten temat prawie nic.

Jeśli chodzi o wpływ modalności na trudność zadania, należy zauważyć, że zarówno wypowiedź pisemna, jak i ustna dzielą wiele wspólnych mechanizmów psycholingwistycznych (Levelt, 1989), lecztrudność w ich realizacji wynika będzie 
przede wszystkim zobciążenia poznawczego w momencie spontanicznego użycia danego kanału przekazu. Grabowski (2007) zwraca uwagę, że obecność publiczności, do której musimy zwrócić się ustnie w czasie rzeczywistym, będzie wymagać jednoczesnego skupiania się na formie i treści języka, co może skutkować obniżeniem wykonania w obu aspektach. W przeciwieństwie do wypowiedzi ustnej, tempo pisania jest zwykle samodzielnie ustalane przez uczących się i wiąże się z możliwością swobodnego przerzucania uwagi pomiędzy poprawnością a bogactwem językowym wypowiedzi. Kuiken i Vedder (2011) wykazali, że wypowiedź pisemna danego ucznia zwykle charakteryzuje się większą złożonością syntaktyczną i większym bogactwem leksykalnym niż jego wypowiedź ustna. Do podobnych wniosków doszła Kormos (2014), która dowiodła, że wypowiedzi pisemne uczniów są zwykle bardziej poprawne, leksykalnie różnorodne i bardziej złożone pod względem syntaktycznym.

Innym czynnikiem wpływającym na trudność zadania jest odnoszenie się do zdarzeń odległych w czasie lub przestrzeni. Zdaniem Robinsona (2001), uczącym się dużo trudniej mówić o zdarzeniach przeszłych niż współczesnych lub opisywać miejsca lub zdarzenia, które dzieją się gdzie indziej niż oni sami. W jednym z badań Robinson (2001,) poprosił grupę 44 uczących się 0 wykonanie prostego zadania polegającego na wskazywaniu kierunków w obrębie znanego miejsca i zadania trudniejszego, w którym uczący się musieli podawać kierunki na podstawie mapy nieznanego miejsca. Żadne z zadań nie wpłynęło znacząco na bogactwo użytego języka, jednak zadanie trudniejsze charakteryzowało się większą poprawnością i mniejszą płynnością. Do podobnych wniosków doszedł Taguchi (2007), w którego badaniu 59 uczących się wykonywało zadania polegające na odgrywaniu ról. W przypadku tego badania trudność została zoperacjonalizowana jako wykonywanie aktów mowy pomiędzy osobami o różnym dystansie społecznym. Uczniowie odgrywali w parach role osób o różnym statusie społecznym. Trudniejsze zadania charakteryzowała zmniejszona płynność i mniejsze bogactwo językowe.

Jeśli chodzi o znajomość kategorii realizowanego zadania, badania koncentrowały się przede wszystkim na powtarzaniu zadań przez uczących się. Jak dowiedziono (Patansorn 2010; Kim, Tracy-Ventura 2013; Thai, Boers 2016), wierne powtórzenie zadania jest najmniej korzystnym typem powtórzenia z punktu widzenia rozwoju płynności, poprawności i bogactwa językowego. O wiele bardziej korzystne okazało się powtórzenie treści pojawiających się w zadaniu, kiedy zmieniono jego kategorię (np. tę samą tematykę wykorzystano raz do narracji, innym razem do poszukiwania argumentów, a następnie do przeprowadzenia debaty). W takim wypadku zaobserwowano pozytywny wpływ na płynność językową uczących się. Z kolei powtórzenie proceduralne (kiedy uczniowie wykonują to samo zadanie, ale zmienia się jego treść) zdaje 
się pozytywnie wpływać zarówno na płynność, jak i poprawność oraz zwiększanie motywacji uczniów do wykonywania ćwiczeń.

Według założeń Robinsona (2001), zwiększanie trudności zadania powinno skierować uwagę uczących się na formy językowe, a tym samym pozytywnie przyczyniać się do zwiększenia poprawności i bogactwa językowego, kosztem zmniejszonej płynności. Wyniki badań są jednak dość niespójne, co wynika najprawdopodobniej z różnych metodologii badawczych. Trudności wynikają z jednej strony z problemów ze zdefiniowaniem i zmierzeniem stopnia trudności zadania, a z drugiej z obranymi miarami. Innymi słowy, trudność zadania zwykle wynika z jego porównania z innym, a nie z konkretnej skali. Z kolei różne miary płynności, poprawności i bogactwa językowego używane w poszczególnych badaniach nie pozwalają na właściwie porównanie tych wyników. M etaanaliza badań nad trudnością zadań komunikacji ustnej (Jackson, Suethanapornkul, 2013) wykazała małą, lecz pozytywną korelację pomiędzy trudnością zadania a bogactwem językowym. Jednak Wang i Skehan (2014) przestrzegają przed wyciąganiem na tej podstawie przedwczesnych wniosków pedagogicznych. Ich zdaniem, tego typu korelacje powinny być analizowane na poziomie pojedynczego uczącego się, a nie grupy gdyż wyniki grup zwykle wykazują wzrosty w poziomie bogactwa językowego, które wynikają z dużych wzrostów u pojedynczych badanych.

\section{Trudność zadania komunikacyjnego a bogactwo leksykalne wypowiedzi uczniów - badanie}

Pomimo znacznej liczby badań dotyczących różnych czynników wpływających na trudność zadania (patrz wyżej), niewiele z nich dotyczyło wykorzystywania procesów myślowych o różnym stopniu trudności. Według naszej wiedzy, nie istnieją żadne badania dotyczące zwiększania trudności zadań poprzez odwoływanie się do procesów myślowych wyższego rzędu, zwłaszcza zaś myślenia kreatywnego. Co więcej, te dotychczas prowadzone w większości koncentrowały się na pomiarze bogactwa językowego bez odróżniania bogactwa syntaktycznego i leksykalnego.

W badaniu przedstawionym poniżej wykorzystano zadania wymagające od uczniów coraz większej kreatywności i zmierzono wpływ takiego postępowania na bogactwo językowe wypowiedzi uczniów. Wzięło w nim udział 28 uczniów języka angielskiego jako obcego, którzy wykonywali po kolei:

- zadanie wymagające wygenerowania pomysłów,

- zadanie wymagające uszeregowania wygenerowanych pomysłów od najbardziej do najmniej ważnych,

- zadanie polegające na wymyśleniu argumentów przeciwko wygenerowanym pomysłom. 


\subsection{Uczestnicy}

Badaniem objęto 28 licealistów, uczniów języka angielskiego. W momencie badania wszyscy ukończyli 16 lat i mieli za sobą co najmniej pięć lat obowiązkowej nauki języka angielskiego w szkole podstawowej. Znajdowali się w drugiej klasie liceum, które oferowało pięć godzin lekcji języka angielskiego tygodniowo, co oznacza, że ich nauczyciel uczył ich przez ponad rok, prowadząc około 150 zajęć po 45 minut. Ich kurs nie opierał się na żadnej konkretnej metodzie, a raczej na eklektycznym podejściu w oparciu o podręcznik English File (wyd. 3, Oxford University Press). Poziom biegłości uczniów w momencie badania można określić jako B2 (w skali ESOKJ) lub średniozaawansowany.

\subsection{Zadania komunikacyjne wykorzystanie w badaniach}

W badaniu wykorzystano trzy zadania komunikacyjne o narastającym stopniu trudności. Każde wymagało od uczących się wykorzystania myślenia kreatywnego, zmieniała się natomiast natura procesów myślowych, jakie należało zaangażować. W pierwszym zadaniu uczący się zostali poproszeni o zaproponowanie dziesięciu pomysłów na to, jak utrzymać dobre zdrowie w okresie kwarantanny narodowej; w drugim - mieli je uporządkować od najważniejszych do najmniej ważnych, a w trzecim zaś - sformułować argumenty podważające zaproponowane przez siebie sposoby działania. Przykładowo, jeśli uczący się wskazali wcześniej, że ważne jest jedzenie warzyw i owoców, to w trzecim zadaniu musieli przedstawić argumenty przeciwko takiej sugestii. Procesy myślowe, jakie należało zaangażować do wykonania poszczególnych zadań, były różne: pierwsze - wymagało przeprowadzenia burzy mózgów, a więc tzw. myślenia dywergencyjnego polegającego na wymyślaniu możliwie dużej liczby pomysłów; drugie - polegało na sortowaniu i porządkowaniu, tj. procesach uznawanych za bardziej wymagające (Willis, Willis, 2008). Zkolei trzecie zadanie wymagało kreatywnego rozwiązywania problemów, a zatem angażowało myślenie asocjacyjne, transformowanie i generowanie alternatywnych rozwiązań (zob. Róg, 2018).

\subsection{Procedura}

Uczniowie zostali objęci badaniem podczas nauczania zdalnego poprzez platformę Zoom. Pozwoliło to na nagranie i sporządzenie zapisu ich wypowiedzi w edytorze tekstu. Zapis nie był szczegółową transkrypcją, pominięto w nim odnotowywanie pauz i zawahań, uznając je za nieistotne w badaniu bogactwa leksykalnego. Spisane wypowiedzi zostały wstępnie przeanalizowane pod kątem różnorodności i gęstości leksykalnej przy wykorzystaniu programu Vocabprofiler. 
które jest obecnie szeroko stosowanym narzędziem typu open source służącym do oceny złożoności leksykalnej w języku angielskim i francuskim dostępnym na stronie Lextutor (Cobb, 2012) ${ }^{1}$.

Uczniowie otrzymywali po jednym zadaniu do wykonania w grupach trzyosobowych, których skład nie zmieniał się przez całą lekcję. Wiązało się to z charakterem zadań, które wymagały pracy na tym samym materiale wygenerowanym przez uczniów w pierwszym zadaniu. Uczniowie nie znali treści kolejnych poleceń, a wyłącznie zadania, nad którym pracowali w danym momencie. $\mathrm{Na}$ wykonanie każdego z nich otrzymali dziesięć minut (w przerwach pomiędzy kolejnymi omawiano pomysły na forum grupy). W trakcie realizacji zadań nauczyciel nie interweniował, tj. nie udzielał informacji korygującej, nie stosował przeformułowań i nie sugerował żadnych odpowiedzi. Uczniowie działali spontanicznie, tj. nie otrzymali czasu na zaplanowanie swoich wypowiedzi.

\subsection{Miary}

W badaniu wzięto pod uwagę siedem miar związanych z bogactwem leksykalnym wypowiedzi uczniów:

- całkowitą liczbę słów w wypowiedzi każdego z uczniów;

- zróżnicowanie leksykalne rozumiane jako stosunek liczby wyrazów niepowtarzających się a występujących w danym tekście do wszystkich wyrazów w nim użytych (okaz vs typ; ang. type-token ratio); im wyższą przybiera wartość, tym większa różnorodność słownictwa: norma to 0,5 dla mowy; 0,7 dla pisma (Foster, Skehan, 2012);

- gęstość leksykalną, stanowiącą stosunek liczby słów niosących treść (autosemantycznych) do wszystkich wyrazów użytych w tekście (na podstawie korpusu Vocabprofiler); im większa gęstość leksykalna, tym tekst uznaje się za mniej czytelny;

- $\quad$ słowa z kategorii K1, tj. z pierwszego tysiąca słów najczęściej występujących w języku angielskim (na podstawie korpusu Vocabprofiler);

- słowa z kategorii K2, tj. z drugiego tysiąca słów najczęściej występujących w języku angielskim;

- $\quad$ angielskie słownictwo akademickie;

- słowa spoza korpusu (np. nazwy własne, akronimy, skrótowce, słownictwo specjalistyczne, bądź po prostu przejęzyczenia).

\footnotetext{
${ }^{1}$ W przypadku języka angielskiego opiera się ono na korpusach British National Corpus i Contemporary Corpus of American English.
} 


\section{Wyniki}

Analizę przeprowadzono z wykorzystaniem pakietu Statistica 12 i arkusza kalkulacyjnego Excel. W pierwszym kroku sprawdzono normalności rozkładów badanych zmiennych/różnic zmiennych ilościowych za pomocą testu W ShapiroWilka. W przypadku porównań 3 lub więcej podgrup, gdy rozkład co najmniej jednej zmiennej odbiegał od normalnego, do porównań wykorzystano nieparametryczny test ANOVA Rang Kruskala-Wallisa. Dodatkowo, w przypadku istotnych różnic między porównywanymi grupami - wykorzystano p dla testu dwustronnego z poprawką Bonferroniego dla porównań wielokrotnych w celu identyfikacji konkretnych par porównań różniących się między sobą. Przy zachowaniu normalności rozkładów wykorzystano jednoczynnikową analizę wariancji ANOVA, a w przypadku zaobserwowania statystycznie istotnych różnic - dodatkowo za pomocą testu NIR (Najmniejszej Istotnej Różnicy), w celu identyfikacji szczegółowych par porównań różniących się między sobą. Przyjęto poziom istotności równy 0,05 . Statystyki opisowe zaprezentowano za pomocą miar pozycyjnych: średniej, mediany, odchylenia standardowego, minimum, maksimum.

\begin{tabular}{|c|c|c|c|c|c|c|}
\hline STATYSTYKI OPISOWE & ZADANIE & ŚREDNIA & MEDIANA & MIN. & MAX. & SD \\
\hline liczba stów & \multirow{7}{*}{ burza mózgów } & 179,2 & 183,0 & 134,0 & 214,0 & 21,8 \\
\hline zróżnicowanie leksykalne & & 0,6 & 0,6 & 0,4 & 0,6 & 0,1 \\
\hline gęstość leksykalna & & 0,5 & 0,5 & 0,4 & 0,5 & 0,0 \\
\hline liczba słów z grupy k1 & & 163,1 & 165,0 & 119,0 & 196,0 & 22,0 \\
\hline liczba słów z grupy k2 & & 6,3 & 6,5 & 2,0 & 10,0 & 2,3 \\
\hline liczba słów akademickich & & 2,4 & 3,0 & 0,0 & 6,0 & 1,9 \\
\hline liczba stów spoza list & & 7,4 & 8,0 & 3,0 & 10,0 & 1,9 \\
\hline liczba słów & \multirow{7}{*}{ szeregowanie } & 247,4 & 242,0 & 186,0 & 353,0 & 44,9 \\
\hline zróżnicowanie leksykalne & & 0,5 & 0,5 & 0,4 & 0,6 & 0,0 \\
\hline gęstość leksykalna & & 0,5 & 0,5 & 0,5 & 0,6 & 0,0 \\
\hline liczba słów z grupy k1 & & 213,4 & 209,0 & 165,0 & 303,0 & 39,4 \\
\hline liczba słów z grupy K2 & & 17,2 & 17,0 & 11,0 & 26,0 & 4,5 \\
\hline liczba stów akademickich & & 3,0 & 2,5 & 0,0 & 6,0 & 2,2 \\
\hline liczba słów spoza list & & 13,8 & 13,0 & 8,0 & 18,0 & 3,2 \\
\hline & \multirow{8}{*}{$\begin{array}{l}\text { przedstawianie } \\
\text { argumentów } \\
\text { „przeciw” }\end{array}$} & & & & & \\
\hline liczba stów & & 443,6 & 462,5 & 304,0 & 521,0 & 59,9 \\
\hline zróżnicowanie leksykalne & & 0,4 & 0,4 & 0,4 & 0,4 & 0,0 \\
\hline gęstość leksykalna & & 0,5 & 0,5 & 0,4 & 0,5 & 0,0 \\
\hline liczba słów z grupy k1 & & 380,4 & 403,0 & 270,0 & 456,0 & 52,4 \\
\hline liczba słów z grupy k2 & & 35,0 & 37,0 & 20,0 & 45,0 & 7,5 \\
\hline liczba stów akademickich & & 5,6 & 5,5 & 1,0 & 10,0 & 3,4 \\
\hline liczba słów spoza list & & 22,4 & 21,5 & 10,0 & 33,0 & 7,5 \\
\hline
\end{tabular}

Tabela 1: Statystyki opisowe uzyskanych wyników. 
Na poziomie istotności 0,05 zaobserwowano statystycznie istotną różnicę ( $p=$ 0,000) między wynikami pomiarów:

- liczby słów uzyskanymi w porównywanych rodzajach zadań; istotne różnice wyników liczby słów obserwuje się między zadaniem "burza mózgów" oraz "szeregowaniem" ( $p=0,000)$ oraz "burzą mózgów" a "przedstawianiem argumentów przeciw" ( $p=0,000)$ a także między „szeregowaniem" a "przedstawianiem argumentów przeciw"; średnia liczba słów w zadaniu „burza mózgów” wynosiła 179,2 (SD+/-21,8) i była istotnie niższa od średniej w zadaniu „szeregowanie” w której wynosiła 247,4 (SD+1-44,9) oraz w zadaniu przedstawianie argumentów przeciw, w której wyniosła ona 443,6 (SD+1-59,9);

\begin{tabular}{|l|r|r|r|r|r|r|r|r|}
\hline $\begin{array}{l}\text { Jednoczynnikowa analiza } \\
\text { wariancji - Anova }\end{array}$ & SS & Df & MS & SS & df & MS & F & P \\
\hline Lizba stów & Efekt & Efekt & Efekt & Błąd & Błąd & Błąd & & \\
\hline
\end{tabular}

Tabela 2: Jednoczynnikowa analiza wariancji.

- różnorodności leksykalnej uzyskanymi w porównywanych rodzajach zadań; istotne różnice różnorodności leksykalnej zaobserwowano między zadaniem „burza mózgów" oraz "szeregowaniem" $(p=0,000)$ oraz „burzą mózgów" a "przedstawianiem argumentów przeciw" ( $p=0,000)$, a także między "szeregowaniem" a "przedstawianiem argumentów przeciw"; średni wynik różnorodności leksykalnej w zadaniu „burza mózgów” wyniósł $0,6(S D+1-0,1)$ i był istotnie wyższy od średniego wyniku w zadaniu „szeregowanie", w którym wyniósł 0,5 (SD+/-0,0) oraz w zadaniu „przedstawianie argumentów przeciw", w którym wyniósł 0,4 (SD+/-0,0);

\begin{tabular}{|l|r|r|r|r|r|r|r|r|}
\hline $\begin{array}{l}\text { Jednoczynnikowa analiza } \\
\text { Wariancji - Anova }\end{array}$ & SS & Df & MS & SS & df & MS & F & p \\
\hline & Efekt & Efekt & Efekt & Błąd & Błąd & Błąd & & \\
\hline Zróżnicowanie leksykalne & 0,2 & 2 & 0,1 & 0,1 & 39 & 0,0 & 40,6 & 0,000 \\
\hline
\end{tabular}

Tabela 3: Zróżnicowanie leksykalne - jednoczynnikowa analiza wariancji.

- gęstości leksykalnej uzyskanymi w porównywanych rodzajach zadań; istotne różnice wyników gęstości leksykalnej obserwuje się między zadaniem „burza mózgów” oraz „przedstawianiem argumentów przeciw” ( $p=0,021)$, a także między „szeregowaniem” a "przedstawianiem argumentów przeciw" ( $p=0,000)$; średnia gęstość leksykalna w zadaniu „burza mózgów” wyniosła 0,49 (SD+/-0,03) i była istotnie wyższa od średniej w zadaniu „przedstawianie argumentów przeciw”, w której wyniosła ona 0,46 (SD+1-0,02); ponadto średnia w zadaniu "szeregowanie” 
była istotnie niższa od średniej w zadaniu „przedstawianie argumentów przeciw", w której wyniosła ona 0,52 (SD+/-0,02);

\begin{tabular}{|l|r|r|r|r|r|r|r|r|}
\hline $\begin{array}{l}\text { Jednoczynnikowa analiza } \\
\text { Wariancji - Anova }\end{array}$ & SS & df & MS & SS & df & MS & F & p \\
\hline & Efekt & Efekt & Efekt & Błąd & Błąd & Błąd & & \\
\hline Gęstość leksykalna & 0,0 & 2 & 0,0 & 0,0 & 39 & 0,0 & 9,1 & 0,001 \\
\hline
\end{tabular}

Tabela 4: Gęstość leksykalna - jednoczynnikowa analiza wariancji.

\begin{tabular}{|l|r|r|r|}
\hline Test nir; zmienna: gęstość leksykalna & Burza mózgów & Szeregowanie & $\begin{array}{r}\text { Przedstawianie } \\
\text { argumentów „przeciw” }\end{array}$ \\
\hline Burza mózgów & & 0,073 & 0,021 \\
\hline Szeregowanie & 0,073 & & 0,000 \\
\hline Przedstawianie argumentów „przeciw” & 0,021 & 0,000 & \\
\hline
\end{tabular}

Tabela 5: Gęstość leksykalna - test najmniejszej istotnej różnicy.

- liczby słów z grupy K1 uzyskanymi w porównywanych rodzajach zadań; istotne różnice wyników stosunku liczby słów z grupy K1 obserwuje się między zadaniem "burza mózgów" oraz "szeregowaniem" $(p=0,002)$ oraz „burzą mózgów" a "przedstawianiem argumentów przeciw" ( $p=0,000)$ a także między "szeregowaniem" a "przedstawianiem argumentów przeciw"; średnia liczba liczby słów z grupy K1 w zadaniu "burza mózgów" wynosiła 163,1 (SD+1-2,2) i była istotnie niższa od średniej w zadaniu "szeregowanie" w której wynosiła 213,4 (SDH-39,4) oraz istotnie niższa od średniej w zadaniu „przedstawianie argumentów przeciw", w której wyniosła ona 380,4 (SD+/-52,4);

\begin{tabular}{|l|r|r|r|r|r|r|r|r|}
\hline $\begin{array}{l}\text { Jednoczynnikowa analiza } \\
\text { Wariancji - Anova }\end{array}$ & $\mathrm{SS}$ & $\mathrm{df}$ & $\mathrm{MS}$ & $\mathrm{SS}$ & $\mathrm{df}$ & $\mathrm{MS}$ & $\mathrm{F}$ & $\mathrm{p}$ \\
\hline & Efekt & Efekt & Efekt & Błąd & Błąd & Błąd & & \\
\hline Liczba słów z grupy k1 & 362354,6 & 2 & 181177,3 & 62204,4 & 39 & 1595,0 & 113,6 & 0,000 \\
\hline
\end{tabular}

Tabela 6: Liczba słów z grupy K1 (pierwszy tysiąc najczęściej występujących słów) jednoczynnikowa analiza wariancji.

\begin{tabular}{|l|r|r|r|}
\hline Test nir; zmienna: liczba stów z grupy k1 & Burza mózgów & Szeregowanie & $\begin{array}{r}\text { Przedstawianie } \\
\text { argumentów „przeciw” }\end{array}$ \\
\hline Burza mózgów & & 0,002 & 0,000 \\
\hline Szeregowanie & 0,002 & & 0,000 \\
\hline Przedstawianie argumentów „przeciw” & 0,000 & 0,000 & \\
\hline
\end{tabular}

Tabela 7: Liczba słów z grupy K1 (pierwszy tysiąc najczęściej występujących słów) test najmniejszej istotnej różnicy. 
- liczby słów z grupy K2 uzyskanymi w porównywanych rodzajach zadań; istotne różnice wyników stosunku liczby słów z grupy K2 obserwuje się między zadaniem „burza mózgów” oraz „szeregowaniem” $(p=0,000)$ oraz "burzą mózgów" a "przedstawianiem argumentów przeciw" ( $p=0,000)$ a także między "szeregowaniem" a "przedstawianiem argumentów przeciw"; średnia liczba liczby słów z grupy K2 w zadaniu „burza mózgów" wynosiła 6,3 (SD+/-2,3) i była istotnie niższa od średniej w zadaniu „szeregowanie”, w której wynosiła 17,2 (SD H-4,5) oraz istotnie niższa od średniej w zadaniu „przedstawianie argumentów przeciw", w której wyniosła ona 35,0 (SD+/-7,5);

\begin{tabular}{|l|r|r|r|r|r|r|r|r|}
\hline $\begin{array}{l}\text { Jednoczynnikowa analiza } \\
\text { wariancji - Anova }\end{array}$ & SS & $\mathrm{df}$ & $\mathrm{MS}$ & $\mathrm{SS}$ & $\mathrm{df}$ & $\mathrm{MS}$ & $\mathrm{F}$ & $\mathrm{p}$ \\
\hline & $\mathrm{Efekt}$ & Efekt & Efekt & Błąd & Błąd & Błąd & & \\
\hline Liczba stów z grupy k2 & 5881,3 & 2 & 2940,6 & 1063,2 & 39 & 27,3 & 107,9 & 0,000 \\
\hline
\end{tabular}

Tabela 8: Liczba słów z grupy K2 (drugi tysiąc najczęściej występujących słów) jednoczynnikowa analiza wariancji.

\begin{tabular}{|l|r|r|r|}
\hline Test nir; zmienna: liczba słów z grupy k2 & Burza mózgów & Szeregowanie & $\begin{array}{r}\text { Przedstawianie } \\
\text { argumentów „przeciw” }\end{array}$ \\
\hline Burza mózgów & & 0,000 & 0,000 \\
\hline Szeregowanie & 0,000 & & 0,000 \\
\hline Przedstawianie argumentów „przeciw” & 0,000 & 0,000 & \\
\hline
\end{tabular}

Tabela 9: Liczba słów z grupy K2 (drugi tysiąc najczęściej występujących słów) - test najmniejszej istotnej różnicy.

- liczby słów akademickich uzyskanymi w porównywanych rodzajach zadań: istotne różnice wyników stosunku liczby słów akademickich obserwuje się między zadaniem „burza mózgów” a "przedstawianiem argumentów przeciw" ( $p=0,002)$ a także między „,Szeregowaniem" a "przedstawianiem argumentów przeciw" ( $p=0,010)$; średnia liczba liczby stów akademickich w zadaniu „burza mózgów” wynosiła 0,6 (SD+/-0,1) i była istotnie wyższa od średniej w zadaniu „przedstawianie argumentów przeciw”, w której wyniosła ona 0,4 (SD+1-0,0); ponadto średnie wyniki w grupie „przedstawianie argumentów przeciw" były istotnie niższe od wyników w zadaniu „szeregowania", w której wynosiły one średnio 0,5 (SD+1-0,0);

\begin{tabular}{|l|r|r|r|r|r|r|r|r|}
\hline $\begin{array}{l}\text { Jednoczynnikowa analiza } \\
\text { Wariancji - Anova }\end{array}$ & $\mathrm{SS}$ & $\mathrm{df}$ & $\mathrm{MS}$ & $\mathrm{SS}$ & $\mathrm{df}$ & $\mathrm{MS}$ & $\mathrm{F}$ & $\mathrm{p}$ \\
\hline & Efekt & Efekt & Efekt & Błąd & Błąd & Błąd & & \\
\hline Liczba słów akademickich & 82,3 & 2 & 41,2 & 262,6 & 39 & 6,7 & 6,1 & 0,005 \\
\hline
\end{tabular}

Tabela 10: Liczba słów „akademickich” - jednoczynnikowa analiza wariancji. 
Tomasz Róg

\begin{tabular}{|l|l|l|l|}
\hline Test nir; zmienna: liczba stów akademickich & Burza mózgów & Szeregowanie & $\begin{array}{l}\text { Przedstawianie } \\
\text { argumentów } \\
\text {,przeciw” }\end{array}$ \\
\hline Burza mózgów & & 0,564 & 0,002 \\
\hline Szeregowanie & 0,564 & & 0,010 \\
\hline Przedstawianie argumentów „przeciw” & 0,002 & 0,010 & \\
\hline
\end{tabular}

Tabela 11: Liczba słów akademickich - jednoczynnikowa analiza wariancji.

- liczby słów spoza list uzyskanymi w porównywanych rodzajach zadań; istotne różnice wyników liczby słów spoza list obserwuje się między zadaniem „burza mózgów" oraz "szeregowaniem" $(p=0,003)$ oraz "burzą mózgów a przedstawianiem argumentów przeciw" $(p=0,000)$; u połowy badanych wykonujących zadanie "burza mózgów" poziom liczby słów spoza list był nie wyższy niż 8,0 (mediana) a u drugiej połowy nie niższy niż 8,0 wobec istotnie wyższej mediany równej 13,0 uzyskanej przy zadaniu "szeregowania” oraz mediany równej 21,5 uzyskanej w zadaniu „wymyślania argumentów przeciw”;

\begin{tabular}{|l|r|r|r|}
\hline $\begin{array}{l}\text { Anova Rang Kruskala-Wallisa; zmienna: } \\
\text { liczba słów spoza list }\end{array}$ & \multicolumn{3}{|r|}{$\begin{array}{r}\text { Test Kruskala-Wallisa: } \\
\mathrm{H}(2, \mathrm{~N}=42)=29,9 \mathrm{p}=, 000\end{array}$} \\
\hline & ważnch & Suma & Sang \\
\hline & 28 & 113,5 & Ranga \\
\hline Burza mózgów & 28 & 325,5 & 8,1 \\
\hline Szeregowanie & 28 & 464,0 & 23,3 \\
\hline Przedstawianie argumentów „przeciw” & & & 33,1 \\
\hline Wartość p dla porównań wielokrotnych & burza mózgów & szeregowanie & $\begin{array}{r}\text { przedstawianie } \\
\text { argumentów „przeciw” }\end{array}$ \\
\hline Burza mózgów & & 0,003 & 0,000 \\
\hline Szeregowanie & 0,003 & & 0,099 \\
\hline Przedstawianie argumentów „przeciw” & 0,000 & 0,099 & \\
\hline
\end{tabular}

Tabela 12: Liczba słów spoza list frekwencyjnych - test Kruskala-Wallisa.

\section{Dyskusja}

Badanie pokazało, że wraz z rosnącą trudnością zadania ucznio wie tworzyli coraz dłuższe wypowiedzi. W płynęło to na wzrost wykorzystania słów z kategorii K1, jak i K2, a zatem uczniowie wypowiadali więcej słów zarówno często, jak i rzadziej używanych. Wzrost liczby tych bardziej wyszukanych był znaczący: średnio 6,3 w przypadku zadania „burza mózgów”, 17,2 w przypadku „szeregowania” i aż 35 w zadaniu „przedstawianie argumentów przeciw”. Wraz z trudnością zadania wzrastało również użycie słów spoza list frekwencyjnych, takich jak np. guys, oxygen, carbon dioxide, digesting, coronavirus, strain, sulphur, yeah. Warto zauważyć, że odnotowano niewielki spadek użycia tzw. słów akademickich, jak np. affect, chemical compounds, computer, energy expand, 
injury, mental, obvious, physical, supplements. Niemniej, patrąc całościowo, wraz z rosnącą trudnością zadań uczniowie używali bardziej bogatego słownictwa. Potwierdza to hipotezę Robinsona (2001), że trudność zadania może stymulować użycie rzadszych struktur językowych.

Wraz ze wzrostem trudności zadań malało zróżnicowanie leksykalne, czyli stosunek leksemów (wyrazów podstawowych) do ich wyrazów tekstowych (np. „mama” to leksem, a "mamie”, "mamą", czy "mamo” to wyrazy tekstowe). Mogłoby to wskazywać na fakt, że uczniowie powtarzali podobne słowa, jednak zróżnicowanie leksykalne nie jest jedyną miarą bogactwa językowego. Dla pełniejszego obrazu należy więc brać pod uwagę oryginalność użytych jednostek i gęstość leksykalną. Jak pokazują wyniki, chociaż różnorodność użytych słów stopniowo spadała wraz z trudnością zadania, to wśród wyrazów używanych przez uczniów było coraz więcej tych rzadszych (tj. z grupy K2) oraz tych spoza list frekwencyjnych (było to zwłaszcza słownictwo specjalistyczne związane ze zdrowiem i skróty myślowe wyrażane za pomocą słów).

Ciekawy rezultat przyniosło porównanie gęstości leksykalnej w poszczególnych zadaniach. Początkowo rosła ona od 0,49 w pierwszym zadaniu do 0,52 w drugim, a następnie zmalała do 0,46 w ostatnim. M niejsza gęstość leksykalna oznacza zazwyczaj większą czytelność tekstu, co bywa równoznaczne z tym, że, że tekst nie jest przesycony zbyt zróżnicowanym słownictwem. Niski wynik gęstości leksykalnej w ostatnim, najtrudniejszym zadaniu oznacza zatem, że uczniowie wyrażali swoje myśli w sposób bardziej klarowny niż w przypadku dwóch poprzednich zadań. Biorąc pod uwagę sekwencję zadań, można by założyć, że mniejsza gęstość leksykalna mogła wynikać z wcześniejszego przygotowania uczniów, tj. wykonania poprzednich zadań dotyczących tej samej tematyki, choć wcześniejsze badanie Nik i Adamsa (2014) wykluczyły związek znajomości tematyki zadania z jakością interakcji pomiędzy uczniami.

Ponieważ czas na wykonanie zadania był za każdym razem ten sam (10 minut), rosnąca liczba słów może wskazywać na to, że zwiększanie trudności prowokowało uczniów do szybszego tempa mowy, które jest jedną z miar płynności językowej (Segalowitz, 2010). Przeczy to wynikom badań Robinsona (2001) i Taguchiego (2007), które powiązały większą trudność zadania ze spadkiem płynności. Zdrugiej strony, możemy uznać, że uczniowie dokonywali w pewnym sensie powtórzenia treści zadania (tj. zdrowie) w obrębie różnych kategorii, co zdaje się sprzyjać większej płynności (Kim i Tracy-Ventura 2013; Thai i Boers 2016). Ponieważ płynność nie była jednak poddana analizie w obecnym badaniu, wniosek ten musi być traktowany z ostrożnością. Jedną z przyczyn zwiększonej liczby słów może być natomiast bardziej motywująca natura zadania - być może im większe wyzwanie poznawcze, tym chętniej uczniowie wypowiadali się na zadany temat. Można również z dużą pewnością 
przyjąć, że z każdym kolejnym zadaniem uczniowie byli coraz lepiej przygotowani do wypowiedzi ustnej, ponieważ mogli się odnieść do swoich poprzednich doświadczeń. Potwierdzałoby to konieczność odpowiedniego sekwencjonowania zadań (Malicka, 2020; Willis, Willis, 2006).

W badaniu udało się częściow o potwierdzić hipotezę Robinsona (2001) i wyniki metaanalizy Jacksona i Suethanapornkula (2013), a mianowicie, że zwiększona trudność zadania wpływa pozytywnie na bogactwo językowe. Ponieważ analizie nie poddano złożoności składni uczniów, możemy jedynie potwierdzić, że im trudniejsze zadanie, tym bardziej stymuluje ono uczniów do wykorzystania bogatszej leksyki. Jak wykazano, trudność zadania sprzyjała nie tylko jakości, ale również ilości wypowiadanych wyrazów, co może wiązać się ze zwiększoną płynnością lub wynikać z konieczności odpowiedniego sekwencjonowania zadań, czyli planowania ich w czasie lekcji od najmniej do najbardziej wymagających poznawczo.

\section{Wnioski}

W przedstawionym badaniu wykazano związki pomiędzy trudnością zadania komunikacyjnego a bogactwem leksykalnym uczniów, którzy je wykonywali. W ramach podejścia zadaniowego, zadania są kluczowe dla rozwoju kompetencji językowej, ponieważ pozwalają uczącym się odbierać i przekazywać dane językowe, a więc poznawać nowe słowa i aktywizować słownik mentalny, skupiając się przede wszystkim na znaczeniu. Jak dotąd badacze manipulowali różnymi aspektami zadania w poszukiwaniu optymalnych warunków jego wykonywania. Wśród przytoczonych powyżej interwencji możemy wymienić manipulowanie czasem na przygotowanie się do wykonania zadania, pozwalanie uczniom na wykonywanie notatek, powtarzanie zadań przez uczniów i wykonywanie zadań o powiązanej tematyce. Niewielu badaczy zajmowało się dotychczas manipulowaniem trudnością zadania poprzez wykorzystywanie procesów poznawczych wyższego rzędu, takich jak np. myślenie kreatywne. Ponadto, większość dostępnych nam badań dotyczy bogactwa językowego uczniów i nie rozgranicza pomiędzy bogactwem leksykalnym a bogactwem semantycznym. W opisanym badaniu skupiliśmy się na bogactwie leksykalnym uczniów, wykorzystując siedem jego miar: ogólną liczbę słów, różnorodność i gęstość leksykalną oraz liczbę słów w czterech kategoriach frekwencyjnych (pierwszy i drugi tysiąc najczęstszych słów, słownictwo akademickie i słownictwo spoza list frekwencyjnych).

Analiza danych uzyskanych od 28 uczniów wykazała istotne statystycznie zmiany w każdej z siedmiu miar bogactwa leksykalnego. Przede wszystkim trudniejsze zadania generowały większą produkcję językową wśród uczniów, 
a jednocześnie użycie mniej powszechnych słów. Oznacza to większe użycie słów z kategorii K2 (drugi tysiąc najczęściej używanych słów) i słów spoza list frekwencyjnych (słownictwo specjalistyczne, skróty, nazwy własne), przy niewielkim obniżeniu użycia słownictwa akademickiego. Jak wykazano, wraz ze stopniem trudności zadania zmalały też różnorodność i gęstość leksykalna, co może wskazywać, że wypowiedzi uczniów w najtrudniejszym zadaniu były bardziej klarowne dla ich rozmówców.

Jakiekolwiek implikacje pedagogiczne powinny być traktowane zdużą ostrożnością, niemniej uzyskane wyniki mogą wskazywać na to, że konstruowanie zadań komunikacyjnych wykorzystujących procesy myślowe wyższego rzędu może pozytywnie wpływać na bogactwo leksykalne wypowiedzi uczących się. W przyszłych badaniach należałoby więc rozpatrzyć, czy zwiększanie się bogactwa leksykalnego nie odbywa się kosztem poprawności i płynności językowej.

\section{Bibliografia}

Adams R., Nik N. (2014), Prior knowledge and second language task production in text chat, (w:) Gonzalez Lloret M., Ortega L. (red.), Technologymediated TBLT: Researching technology and tasks. Philadelphia, PA: John Benjamins, s. 51-78.

Breen M. (1989), The evaluation cycle for language learning tasks, (w:) Johnson R.K. (red.), The second language curriculum. Cambridge: Cambridge University Press, s. 187-206.

Bygate, M. (2018), Learning language through task repetition. Amsterdam: John Benjamins Publishing Company.

Cho M. (2018), Task complexity, modality, and working memory in L2 task performance. "System", nr 72, s. 85-98.

Cobb T. (2012), Compleat lexical tutor, http:// www.lextutor.ca/

Ellis R. (2003), Task-based language learning and teaching, Oxford: Oxford University Press.

Ellis R., Li S., Zhu Y. (2018), The effects of pre-task explicit instruction on the performance of a focused task. „System", nr 80, s. 38-47.

Ellis R., Shintani N. (2014), Exploring language pedagogy through second language acquisition research. London \& New York: Routledge.

Ellis R., Skehan P., Li S., Shintani N., Lambert C. (2020), Task-based language teaching. Theory and practice. Cambridge: Cambridge University Press.

Foster P., Skehan P. (2012), Complexity, accuracy, fluency and lexis in taskbased performance: A meta-analysis of the Ealing research, (w:) Housen A., Kuiken F., Vedder I. (red.) Dimensions of L2 Performance and 
Proficiency. Complexity, Accuracy and Fluency in SLA. Amsterdam: John Benjamins Publishing Company, s. 199-220.

Fu M., L S. (2017), The associations between the cognitive process of task performance and working memory. „M odern Foreign Languages” nr 40, s. 114- 124. Gębal P. (2019), Dydaktyka języków obcych. Wprowadzenie. Warszawa: PWN. Grabowski J. (2007), The writing superiority effect in the verbal recall of knowledge: Sources and determinants (w:) Rijlaarsdam G., Torrance M., VanWaes L., Galbraith D. (red.), Writing and cognition: Research and applications. Amsterdam: Elsevier, s. 165-179.

Jackson D.O., Suethanapornkul S. (2013), The cognition hypothesis: A synthesis and meta-analysis of research on second language task complexity. "Language Learning", nr 63(2), s. 330-367.

Janowska I. (2019), Wypowiedź ustna w dydaktyce językowej na przykładzie języka polskiego jako obcego. Kraków: Księgarnia Akademicka.

Kim Y. (2015), The role of tasks as vehicles for learning in classroom interaction, N. Markee

N. (red.), Handbook of classroom discourse and interaction. Malden, MA: Wiley-Blackwell, s. 163-181.

Kim Y., Tracy-Ventura N. (2013), The role of task repetition in 12 performance development: What needs to be repeated during task-based interaction? "System", nr 41, s. 829-840. https://doi.org/10.1016/j.system.2013.08.005

Kormos J. (2014), Differences across modalities of performance: An investigation of linguistic and discourse complexity in narrative tasks, (w:) Byrnes H., Manch R.M. (red.), Task-based language learning: Insights from and for L2 writing. Amsterdam: John Benjamins, s. 193-216.

Kuiken F., Vedder I. (2011), Task complexity and linguistic performance in L2 writing and speaking: The effect of modelling, (w:) Robinson P. (red.), Second language task complexity: Researching the Cognition Hypothesis of language learning and performance. Amsterdam: John Benjamins, s. 91-104. Levelt W.J.M. (1989), Speaking: From intention to articulation. Cambridge, MA: The MIT Press.

Li L., Chen J., Sun L (2015), The effects of different lengths of pre-task planning time on 12 learners' oral test performance. "TESOL Quarterly", nr 49, s. 38-66.

Li S., Fu M . (2016), Strategic and unpressured within-task planning and their associations with working memory. „Language Teaching Research”, nr 22, s. 230-253.

Long M. (2015), Second Language Acquisition and Task-Based Language Teaching. Oxford: Wiley Blackwell. 
Mehnert U. (1998), The effects of different lengths of time for planning on second language Performance. "Studies in Second Language Acquisition", nr 20, s. 52-83.

Nunan D. (2004), Task-based language teaching. Cambridge: Cambridge University Press.

Ortega L. (1999), Planning and focus on form in L2 oral performance. „Studies in second language acquisition", nr 21, s. 109-148.

Park S. (2010), The effect of pre-task instructions and pre-task planning on focus on form during Korean EFL task-based interaction. „Language Teaching Research", nr 14, s. 9-26.

Patanasorn, C. (2010), Effects of procedural, content, and task repetition on accuracy and fluency in an EFL context (niepublikowana rozprawa doktorska). Northern Arizona University, Flagstaff, AZ.

Philp J., Oliver R., M ackey A. (2006), The impact of planning time on children's task-based Interactions. "System", nr 34(4), s. 547-565.

Préfontaine Y., Kormos J. (2015), The relationship between task difficulty and second language fluency in French: a mixed methods approach. "The M odern Language Journal", nr 99 (1), s. 96-112.

Rada Europy. (2003). Europejski system opisu kształcenia językowego. Warszawa: CODN.

Révész A., Gurzynski-Weiss L. (2016), Teachers' perspectives on second language task difficulty: insights from think-aloud and eye tracking. „Annual Review of Applied Linguistics", nr 36, s. 182-204.

Robinson P. (2001), Task complexity, cognitive resources, and syllabus design:

A triadic framework for examining task influences on SLA, (w:) Robinson

P. (red.), Cognition and second language instruction. Cambridge: Cambridge University Press, s. 287-318.

Róg T. (2018), Kreatywność a skuteczne nauczanie języków obcych. „J ęzyki Obce w Szkole", nr 3, s. 93-98.

Róg T. (2020), Nauczaniejęzyków obcych. Teoria, badania, praktyka. Lublin: Werset. Skehan P. (1998), A cognitive approach to language learning, Oxford: Oxford University Press.

Skehan P. (2009), M odelling second language performance. Integrating complexity, accuracy, fluency and lexis. „Applied Linguistics”, nr 30, s. 510-532.

Taguchi N. (2007), Task difficulty in oral speech act production. „Applied Linguistics", nr 28/1, s. 113-135.

Thai C., Boers F. (2016), Repeating a monologue under increasing time pressure: Effects on fluency, accuracy, and complexity. "TESOL Quarterly", nr 50, s. 369-393. 
Wang Z., Skehan P. (2014), Structure, lexis, and time perspectives: Influences on task performance, (w:) Skehan, P. (red.), Processing perspectives on task performance. Amsterdam: John Benjamins, s. 155-185.

Wigglesw orth G., Elder C. (2010), An Investigation of the Effectiveness and Validity of Planning Time in Speaking Test Tasks. „Language Assessment Quarterly", nr 7(1), s. 1-24.

Wigglesworth G. (1997), An investigation of planning time and proficiency level on oral test discourse. „Language Testing”, nr 14, s. 85-106.

Willis D., Willis J. (2008), Doing task-based teaching. Oxford: Oxford University Press.

Received: 03.01.2021

Revised: 11.03 .2021 